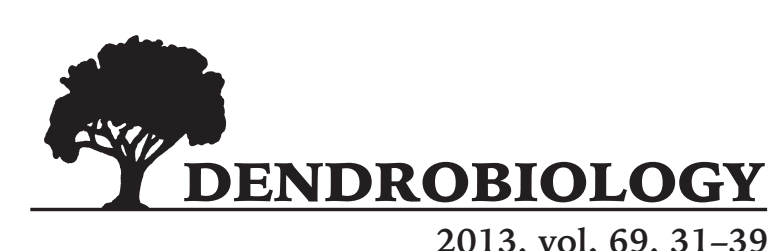

2013, vol. 69, 31-39

\author{
Anissa Boubaya, Hédia Hannachi, Nidhal Marzougui, Tebra Triki, \\ Ferdaws Guasmi, Ali Ferchichi
}

\title{
Genetic diversity assessment of Lawsonia inermis germplasm in Tunisian coastal oases by ISSR and RAPD markers
}

Received: 2 February 2012; Accepted 20 September 2012

\begin{abstract}
Genetic relationships were estimated among 25 germplasm belonging to Lawsonia inermis L. using RAPD and ISSR markers. These markers were implemented in analyses of principal coordinates (PCO), unweighted pair group mean average (UPGMA). Results showed that the L. inermis L. germplasm divided on three groups based on RAPD data. However, using the ISSR data, all studied germplasm were grouped in one group which is divided on three sub-groups, exception four germplasm. The overall mean genetic similarity based on ISSR data ranged from 0.1 to 0.83 and from 0.07 to 0.83 based on RAPD data. The PCO applied on 25 germplasm using ISSR markers showed three groups constituting the three sub-groups obtained in dendrogram based on UPGMA method.

Based on RAPD data, the PCO and dendrogram defined three groups; only one group seemed to be the same in the two applied analyses. The groups obtained based on ISSR and RAPD were independently from their geographical origin. Therefore the ISSR and RAPD molecular markers show two genetic grouping of $L$. inermis L. germplasm which would be as the first step to understand and to conserve these resources characterizing by genetic erosion in these localities.
\end{abstract}

Additional key words: molecular markers, genetic diversity, oases ecosystem

Addresses: A. Boubaya, H. Hannachi, N. Marzougui, T. Triki, F. Guasmi, A. Ferchichi Laboratoire d'Arido Culture et Cultures Oasiennes, Institut des Régions Arides, 4119 Médenine Tunisia, e-mail: anissaboubaya07@yahoo.fr

H. Hannachi, Département de Biologie, Faculté des Sciences de Tunis, Campus universitaire, 2092, Tunisia

\section{Introduction}

Lawsonia is monotypic genus, represented by $L$. inermis, native of North Africa and south-west Asia and is widely cultivated as an ornamental and dye plant throughout India (Grieve 2005), and is commonly known as Henna. It is a popular skin and hair coloring agent in many parts of the world. It is a biennial dicotyledonous herbaceous shrub. Geographically Henna is distributed in Egypt, Arabic countries, Persian countries, India, Pakistan, the USA (Florida), China, and Sudan (Kokate 2001). Lawsonia inermis L. is well known as ethnomedicinal plant and by its cosmetic and medicinal uses for over 9,000 years (Chaudhary et al. 2010; Makhija et al. 2011). Henna leaves, flowers, seeds, stem bark and roots are used in traditional medicine.

The plant characterized by wide range of phytochemicals including carbohydrates, glycosides, tannins, phenolic compounds, gums, mucilage, naptho- 
quinone derivatives, terpenoids, sterols, aliphatic derivatives, xanthones, coumarin, fatty acids, amino acids and other constituents (Chaudhary et al. 2010; Makhija et al. 2011). Previous studies were conducted on the derived products (Gupta et al. 1992; Keheyan and Giulianelli 2006; Jain et al. 2010) and on biological activity of Lawsonia inermis L. (Singh and Pandey 1998; Rout et al. 2001; Mikhaeil et al. 2004; Endrini 2007; Zumrutdal et al. 2008). However little is known about genetic of Lawsonia inermis L. Hanson et al. (2001) investigated the first nuclear DNA C-values for Henna; obtaining the data for the chromosomes number $(2 \mathrm{n}=$ 30-34) and nuclear DNA content [4C] (1.36 \pm 0.13 $\mathrm{pg})$. The genetic characterization of Lawsonia inermis using molecular markers such as Random Amplified Polymorphic DNA (RAPD) and Inter Simple Sequence Repeats (ISSR) has not been documented. The molecular markers, such as RAPD and ISSR were used to many purposes, i.e. to estimate the genetic diversity within plants (dela Hoz et al. 1996; Esselman et al. 1999), for DNA finger-printing (Moreno et al. 1998), for population genetic studies (Wolfe et al. 1998; Nebauer et al. 1999), and for phylogenetic studies (Hess et al. 2000). It has been reported that the PCR based method for DNA profiling RAPD (Welsh and Clelland 1990; Williams et al. 1990) and ISSR (Bornet and Branchard 2001; Zietkiewicz et al. 1994) were used to identify the duplicates or sort the gemplasm and to estimate genetic diversity among the plants.

Lawsonia has different colors of flowers. In India, the plant of Henna has four flower colors; white, pink, yellow and dark rose (Cartwright-Jones 2005; Singh et al. 2005).

Random amplified polymorphic DNA (RAPD) constitutes an effective means of investigating genetic diversity within or among germplasm, used in many plant species (Jover et al. 2003; Nowakowska et al. 2004; Boulila et al. 2010).

Production of RAPD markers is simple, fast, and low in cost, and it can be done with small amounts of DNA. Another advantage of RAPD markers is that a set of arbitrary primers can be utilized for any organism. The technique has some disadvantages, including high susceptibility to PCR conditions, which results in low reproducibility and amplification of artefact markers. However, the ISSRs are very promising genetic markers for cultivar identification. Their good discrimination efficiency and high reproducibility make them particularly suitable to identify the closely related clones which are often the result of very local selection in several species.

All prospection's made in the Oasis of Gabès, constituting the main region of Henna culture in Tunisia, showed only the white flower type.

The aim of this study is to evaluate the genetic similarity within Lawsonia inermis L. germplasm collected from five localities in the Oasis of Gabès, using RAPD and ISSR markers. It would be important to give information about genetic diversity of Lawsonia inermis and to develop genetic improvement programs and elaborate conservation strategies of this specie.

\section{Materials and Methods}

\section{Plant materials}

25 germplasm of Lawsonia inermis L. were collected from five localities in the coastal oases of Gabès in the South-east of Tunisia (Table 1). All individuals from different germplasm have been deposited in Elfejeh, located in the South-east of Tunisia (Latitude 33 $3^{\circ} 35^{\prime}$ N, Longitude $10^{\circ} 48^{\prime} 3^{\prime \prime} \mathrm{E}$, Altitude $105 \mathrm{~m}$ ).

\section{DNA Extraction}

Fresh young Henna leaves were harvested for each germplasm. Plant DNA was extracted by the cetyltrimethyl ammonium bromide (CTAB) method with some modi? cations (Aras et al. 2003).

\section{ISSR analysis}

Two ISSR primers were tested (Table 2). The conditions for ISSR were: $100 \mathrm{ng}$ of template DNA, $1.5 \mathrm{mM}$ of $\mathrm{MgCl}_{2}, 0.4 \mathrm{mM}$ of dNTPs, $10 \mu \mathrm{M}$ of primer, $0.2 \mathrm{U}$ of Taq DNA polymerase $2 \mu \mathrm{l}$ of $10 \times$ reaction buffer (Fermentas) in a total volume of $20 \mu \mathrm{l}$. The PCR program was $5 \mathrm{~min}$ at $94^{\circ} \mathrm{C}$ for initial denaturation, followed by 35 cycles of $1 \mathrm{~min}$ at $94^{\circ} \mathrm{C}, 1 \mathrm{~min}$ at $52^{\circ} \mathrm{C}, 1$ min at $72^{\circ} \mathrm{C}$ and a final 7 min extension at $72^{\circ} \mathrm{C}$ in a Cleaver thermal cycler.

\section{RAPD analysis}

The primers listed in Table 2 were used to amplify gene segments of Lawsonia inermis germplasm in the following PCR condition: 30 ng of template DNA, 2

Table 1. Location, latitude, longitude and altitude of the Lawsonia inermis L. germplasm in Gabès oasis

\begin{tabular}{|c|c|c|c|c|c|}
\hline Code & Germplasm & Locality & Latitude $(\mathrm{N})$ & Longitude (E) & Altitude (m) \\
\hline L1, L2, L3 & Bou Said I, II and III & Bou Said & $34^{\circ} 06^{\prime}$ & $9^{\circ} 59^{\prime}$ & 11 \\
\hline L4, L5 & Mdou I and II & Mdou & $33^{\circ} 48^{\prime}$ & $10^{\circ} 04^{\prime}$ & 46 \\
\hline L6, L7, L8, L9 & Bsissi I, II, III and IV & Bsissi & $33^{\circ} 59^{\prime}$ & $10^{\circ} 01^{\prime}$ & 3 \\
\hline $\begin{array}{l}\text { L10, L11, L12, L13, L14, L15, } \\
\text { L16, L17, L18, L19 }\end{array}$ & $\begin{array}{l}\text { Awled Elhej I, II, III, IV, Chatt Elfarik } \\
\text { I, II, III, and IV, Ghassena I and II }\end{array}$ & Chenini & $33^{\circ} 53^{\prime}$ & $10^{\circ} 03^{\prime}$ & 24 \\
\hline L20, L21, L22, L23, L24, L25 & Chatt Essalem I, II, III, IV, V and VI & Chatt Essalem & $33^{\circ} 53^{\prime}$ & $10^{\circ} 06^{\prime}$ & 3 \\
\hline
\end{tabular}


Table 2. Details of RAPD and ISSR primers used to characterize Lawsonia inermis L. germplasm

\begin{tabular}{llcc}
\hline \multicolumn{1}{c}{ Primer } & Sequence & $\begin{array}{c}\text { Annealing } \\
\text { temperature }\left({ }^{\circ} \mathrm{C}\right)\end{array}$ & $\begin{array}{c}\text { Number of } \\
\text { amplified bands }\end{array}$ \\
\hline RAPD & & & \\
AX16 & GTCTGTGCGG & 34 & 6 \\
AT & CAGTGGTTCC & 34 & 17 \\
AF14 & GGTGCGCACT & 34 & 5 \\
\hline ISSR & & & \\
A2 & (AG) 8 T & 52 & 4 \\
A6 & (AC) $8 G$ & 52 & 8 \\
\hline
\end{tabular}

$\mathrm{mM}$ of $\mathrm{MgCl}_{2}, 0.3 \mathrm{mM}$ of dNTPs, $15 \mu \mathrm{M}$ of each primer, $0.2 \mathrm{U}$ of Taq DNA polymerase $2 \mu \mathrm{l}$ of $10 \times$ reaction buffer (Fermentas) in a total volume of $20 \mu \mathrm{l}$. PCR was carried out in GeneAmp PCR System 9700 thermal cycler with the following reaction profile: 4 min at $94^{\circ} \mathrm{C}$ for initial denaturation, followed by 40 cycles of $15 \mathrm{sec}$ at $94^{\circ} \mathrm{C}, 15 \mathrm{sec}$ at $34^{\circ} \mathrm{C}, 15 \mathrm{sec}$ at $72^{\circ} \mathrm{C}$, $7 \mathrm{~min}$ at $72^{\circ} \mathrm{C}$ and a final $7 \mathrm{~min}$ extension at $4^{\circ} \mathrm{C}$.

\section{Data analysis}

Only reproducible and well-defined bands, revealed by gel pro analyzer in the replications were considered as potential polymorphic markers. For each primer, the bands were scored as 1 (present) or 0 (absent) and a similarity matrix using the similarity coefficient of Jaccard (1908) was constructed from the ISSR and RAPD data.

Jaccard's genetic similarity index (GSI) was calculated using the following formula:

$$
\operatorname{GSI}(X Y)=a /(a+b+c)
$$

where $\mathrm{X}$ and $\mathrm{Y}$ are the samples

$a$ is the number of markers shared between samples $\mathrm{X}$ and $\mathrm{Y}$,

$\mathrm{b}$ is the number of fragments present in sample $\mathrm{X}$ but absent in sample $\mathrm{Y}$,

$\mathrm{c}$ is the number of fragments absent in sample $\mathrm{X}$, but present in sample Y.

The mean genetic similarity index (MGSI) was calculated as MGSI $=\Sigma$ GSIs $/ \mathrm{n}$, where $\mathrm{n}$ is the total number of GSIs.

Table 3. Similarity matrix of 25 Lawsonia inermis L. germplasm based on Jaccard's coefficient using ISSR data

\begin{tabular}{|c|c|c|c|c|c|c|c|c|c|c|c|c|c|c|c|c|c|c|c|c|c|c|c|c|c|}
\hline & L1 & L2 & L3 & L4 & L5 & L6 & L7 & L8 & L9 & L10 & L11 & L12 & L13 & L14 & L15 & L16 & L17 & L18 & L19 & L20 & L21 & L22 & L23 & L24 & L25 \\
\hline L1 & 1 & & & & & & & & & & & & & & & & & & & & & & & & \\
\hline L2 & 0.25 & 1 & & & & & & & & & & & & & & & & & & & & & & & \\
\hline L3 & 0.5 & 0.5 & 1 & & & & & & & & & & & & & & & & & & & & & & \\
\hline L4 & 0.7 & 0.22 & 0.3 & 1 & & & & & & & & & & & & & & & & & & & & & \\
\hline L5 & 0 & 0 & 0 & 0 & 1 & & & & & & & & & & & & & & & & & & & & \\
\hline L6 & 0.25 & 1 & 0.5 & 0.22 & 0 & 1 & & & & & & & & & & & & & & & & & & & \\
\hline L7 & 0.556 & 0.33 & 0.43 & 0.67 & 0 & 0.33 & & & & & & & & & & & & & & & & & & & \\
\hline L8 & 0 & 0 & 0 & 0 & 0 & 0 & 0 & 1 & & & & & & & & & & & & & & & & & \\
\hline L9 & 0.4 & 0.33 & 0.43 & 0.5 & 0.2 & 0.33 & 0.71 & 0 & 1 & & & & & & & & & & & & & & & & \\
\hline L10 & 0.444 & 0.4 & 0.5 & 0.56 & & 0.4 & 0.57 & 0 & 0.57 & & & & & & & & & & & & & & & & \\
\hline L11 & 0.375 & 0.67 & 0.75 & 0.33 & & 0.67 & 0.5 & 0 & 0.5 & 0.6 & 1 & & & & & & & & & & & & & & \\
\hline L12 & 0.333 & 0.5 & 0.6 & 0.44 & & 0.5 & 0.43 & 0 & 0.43 & 0.8 & 0.75 & & & & & & & & & & & & & & \\
\hline L13 & 0.25 & 1 & 0.5 & 0.22 & & 1 & 0.33 & 0 & 0.33 & 0.4 & 0.67 & 0.5 & 1 & & & & & & & & & & & & \\
\hline L14 & 0.444 & 0.4 & 0.5 & 0.4 & 0 & 0.4 & 0.57 & 0 & 0.37 & 0.25 & 0.33 & 0.28 & 0.4 & 1 & & & & & & & & & & & \\
\hline L15 & 0.556 & 0.33 & 0.43 & 0.5 & 0 & 0.33 & 0.5 & 0 & 0.33 & 0.22 & 0.28 & 0.25 & 0.33 & 0.83 & & & & & & & & & & & \\
\hline L16 & 0.375 & 0.67 & 0.75 & 0.2 & 0 & 0.67 & 0.28 & 0 & 0.28 & 0.33 & 0.5 & 0.4 & 0.67 & 0.6 & 0.5 & 1 & & & & & & & & & \\
\hline L17 & 0.25 & 0.33 & 0.5 & 0.1 & 0 & 0.33 & 0.14 & 0 & 0.14 & 0.17 & 0.25 & 0.2 & 0.33 & 0.4 & 0.33 & 0.67 & & & & & & & & & \\
\hline L18 & 0.5 & 0.5 & 0.6 & 0.3 & 0 & 0.5 & 0.43 & 0 & 0.43 & 0.5 & 0.4 & 0.33 & 0.5 & 0.5 & 0.43 & 0.75 & 0.5 & 1 & & & & & & & \\
\hline L19 & & 0 & 0 & 0 & 0 & 0 & 0 & 0 & 0 & 0 & 0 & 0 & 0 & 0 & 0 & 0 & 0 & 0 & 1 & & & & & & \\
\hline L20 & 0.125 & 0 & 0.25 & 0 & 0 & 0 & 0 & 0 & 0 & 0 & 0 & 0 & 0 & 0.2 & 0.17 & 0.33 & 0.5 & 0.250 & 0 & 1 & & & & & \\
\hline L21 & & 0 & 0 & 0 & 0 & 0 & 0 & 0 & 0 & 0 & 0 & 0 & 0 & 0 & 0 & 0 & 0 & 0 & 0 & 0 & 1 & & & & \\
\hline L22 & 0.125 & 0 & 0.25 & 0 & 0 & 0 & 0 & 0 & 0 & 0 & 0 & 0 & 0 & 0.2 & 0.17 & 0.33 & 0.5 & 0.250 & 0 & 1 & 0 & 1 & & & \\
\hline L23 & 0.125 & 0.5 & 0.25 & 0.11 & 0 & 0.5 & 0.67 & 0 & 0.17 & 0.2 & 0.33 & 0.25 & 0.5 & 0.2 & 0.167 & 0.33 & 0 & 0.250 & 0 & 0 & 0 & 0 & 1 & & \\
\hline L24 & 0.222 & 0.25 & 0.4 & 0.2 & 0 & 0.25 & 0.28 & 0 & 0.28 & 0.14 & 0.2 & 0.17 & 0.25 & 0.6 & 0.5 & 0.5 & 0.25 & 0.40 & 0 & 0.330 & 0 & 0.33 & 0.33 & 1 & \\
\hline L25 & 0 & 0 & 0 & 0 & 0 & 0 & 0 & 0 & 0 & 0 & 0 & 0 & 0 & 0 & 0 & 0 & 0 & 0 & 0 & 0 & 0 & 0 & 0 & 0 & 1 \\
\hline
\end{tabular}




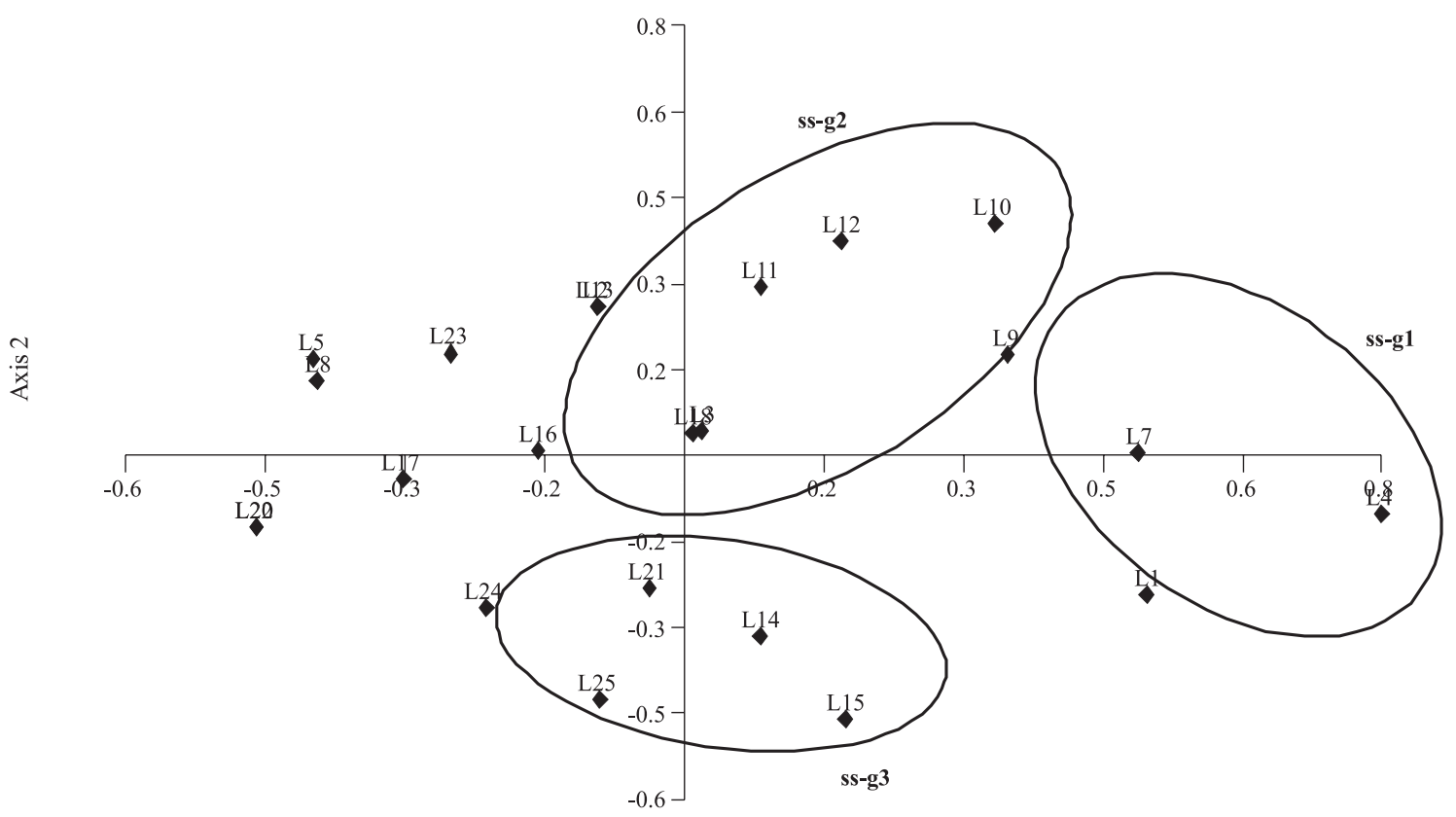

Axis 1

Fig. 1. PCO analysis applied on 25 Tunisian Lawsonia inermis germplasm based on ISSR data. The axes 1 and 2 explain 33.033 and $19.233 \%$ of inertia, respectively

In each germoplasm and oasis group, the genetic diversity was estimated using the percentage of polymorphic bands $\mathrm{P} \%$ [(number of polymorphic bands/number of total bands) $\times 100)]$ and Shannon's index for each RAPD locus $\left(\mathrm{H}^{\prime}\right)$ was calculated as: $\mathrm{H}^{\prime}=-\Sigma p i \log 2 p i$; where $p \mathrm{i}$ is the frequency of the presence or absence of a RAPD band in a germplasm.

Multivariate cluster analysis and principal coordinate analysis (PCO) were used to analyze the data. PCO is an ordination method similar to principal component analysis, except that PCO uses the distance matrix, rather than the values, to plot the axes (Manly 1994). An Unweighted Pair Group Mean Average (UPGMA) dendrogram and spatial representation based on Jaccard's coefficient matrix were used to illustrate the relationships among the germplasm using the software Multi-Variate Statistical Package (MVSP) Plus version 3.12e (Kovach computer services, Anglesey, UK).

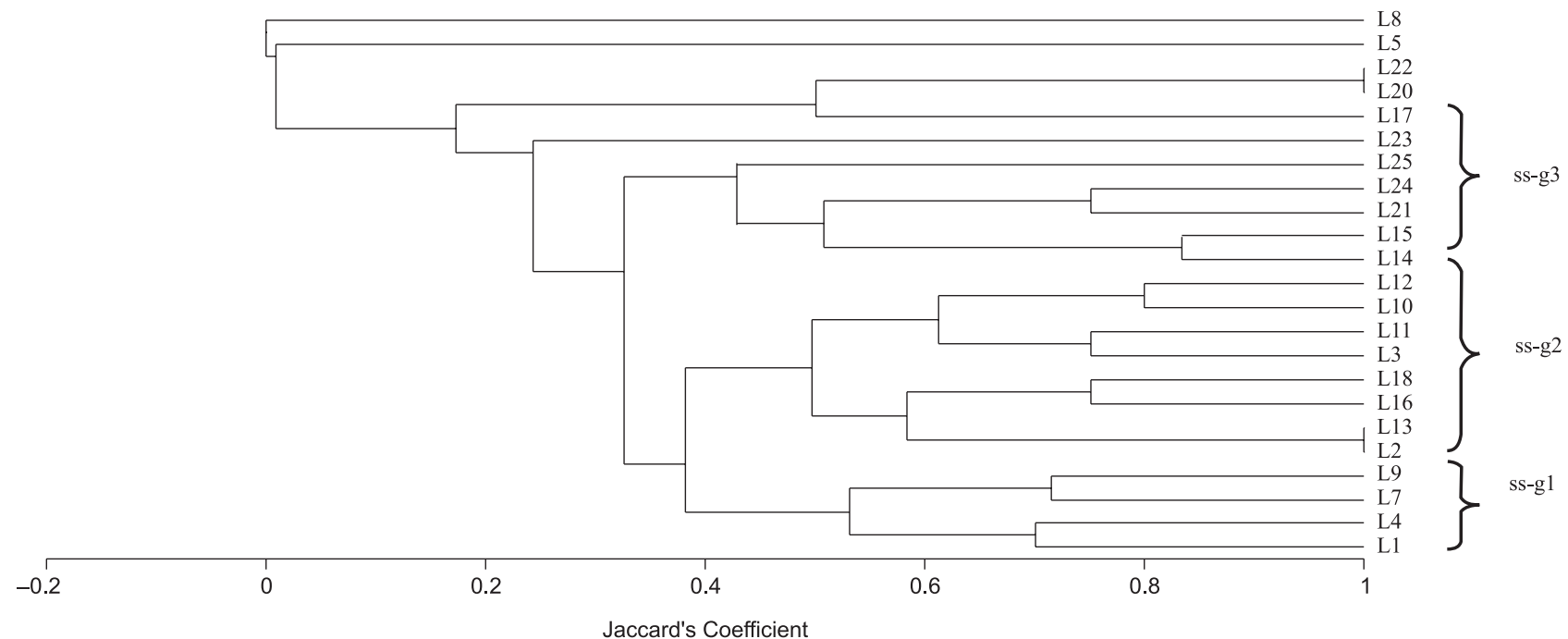

Fig. 2. UPGMA phenogram based on ISSR data using Jaccard coefficient in the total of 25 Tunisian Lawsonia inermis germplasm 
Table 4. Shannon's index in 25 Lawsonia inermis L. germplasm based on ISSR and RAPD data

\begin{tabular}{ccc}
\hline \multirow{2}{*}{ Germplasm } & \multicolumn{2}{c}{ Markers } \\
\cline { 2 - 3 } L1 & ISSR - H' & RAPD-H' \\
\hline L2 & 2.079 & 1.792 \\
L3 & 0.693 & 1.609 \\
L4 & 1.386 & 2.079 \\
L5 & 2.197 & 2.708 \\
L6 & 0 & 1.946 \\
L7 & - & 0.693 \\
L9 & 1.792 & 2.565 \\
L10 & 1.792 & 2.303 \\
L11 & 1.609 & 2.197 \\
L12 & 1.099 & 2.398 \\
L13 & 1.386 & 2.398 \\
L14 & 0.693 & 2.079 \\
L15 & 1.609 & 1.792 \\
L16 & 1.792 & 1.386 \\
L17 & 1.099 & 2.197 \\
L18 & 0.693 & 2.197 \\
L19 & 1.386 & 2.303 \\
L20 & - & 0 \\
L21 & 0 & 1.946 \\
L22 & 1.386 & 1.946 \\
L23 & 0 & 2.303 \\
L24 & 0 & 1.792 \\
L25 & 1.099 & 0.693 \\
& 1.386 & 1.792 \\
\hline
\end{tabular}

Table 5. Eigenvalues and inertia percentage of axes of PCO analysis applied on ISSR and RADP data

\begin{tabular}{lrcr}
\hline & Axis 1 & Axis 2 & Axis 3 \\
\cline { 2 - 4 } & \multicolumn{3}{c}{ ISSR data } \\
\hline Eigenvalues & 2.692 & 1.545 & 1.009 \\
Percentage & 33.033 & 19.233 & 12.439 \\
& & RAPD data \\
Eigenvalues & 1.692 & 1.063 & 0.847 \\
Percentage & 24.283 & 15.263 & 12.153 \\
\hline
\end{tabular}

\section{Results}

\section{Genetic relationship between Lawsonia inermis germplasm}

\section{ISSR data}

Cultivars identification and classification on the basis of the polymorphism generated by the two ISSR primers (A2 and A6) of 25 Lawsonia inermis germplasm were performed. The overall MGSI calculated for 25 germplasm based on ISSR data ranged from 0.1 (between L4-MdouI and L17- Chatt Elfarik IV individuals) to 0.83 (between L14- and L15 from Chenini individuals) (Table 3). For ISSR markers applied, the Shannon's index varied from 0.693 (L2, L13 and L17 individuals) to 2.197 (L4).

The PCO analysis and the dendrogram generated on ISSR data and grouping by UPGMA method based on Jaccard's coefficient were reported in Figure 1 and 2 , respectively. The dendrogram based on UPGMA

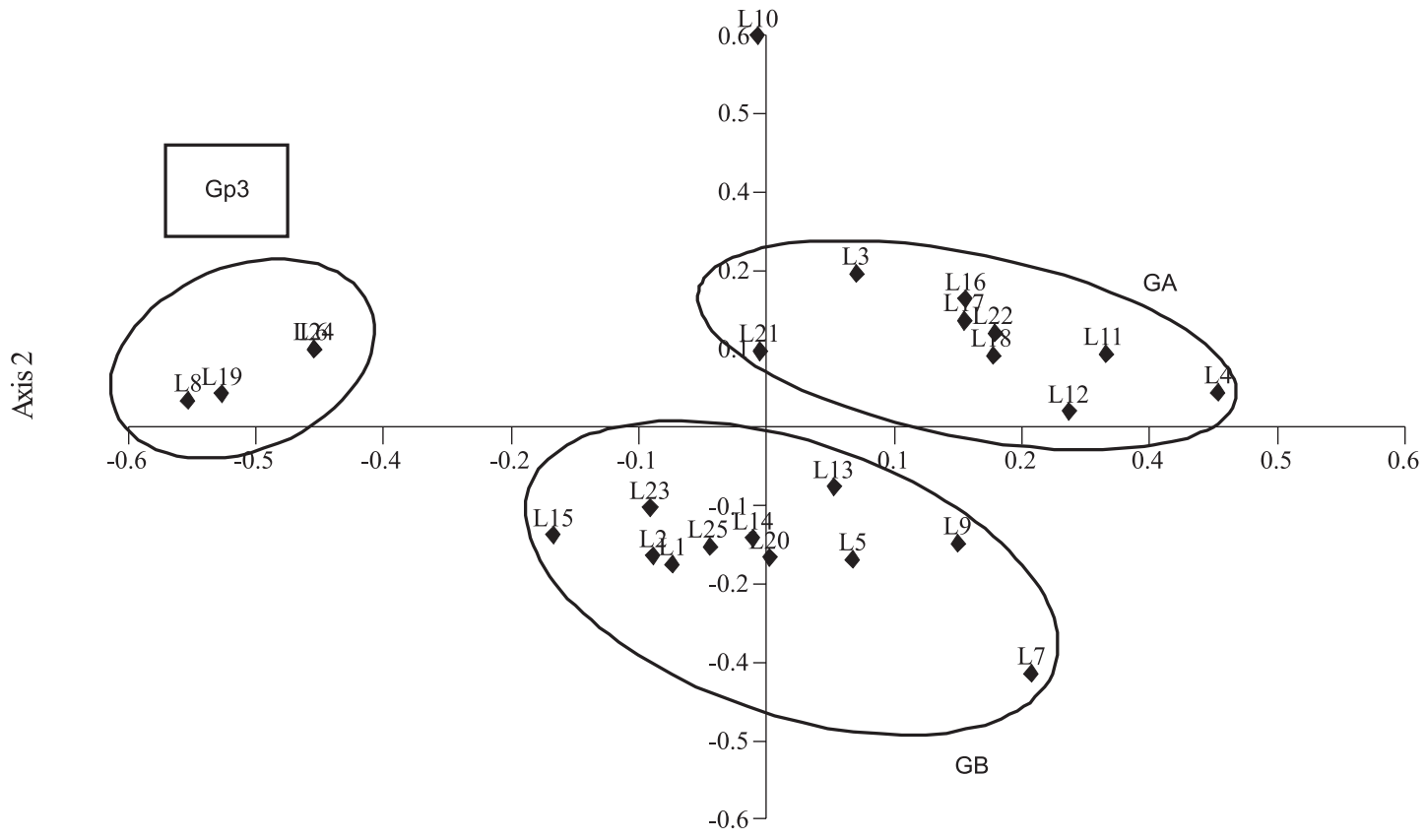

Axis 1

Fig. 3. PCO analysis applied on 25 Tunisian Lawsonia inermis germplasm based on RAPD data 


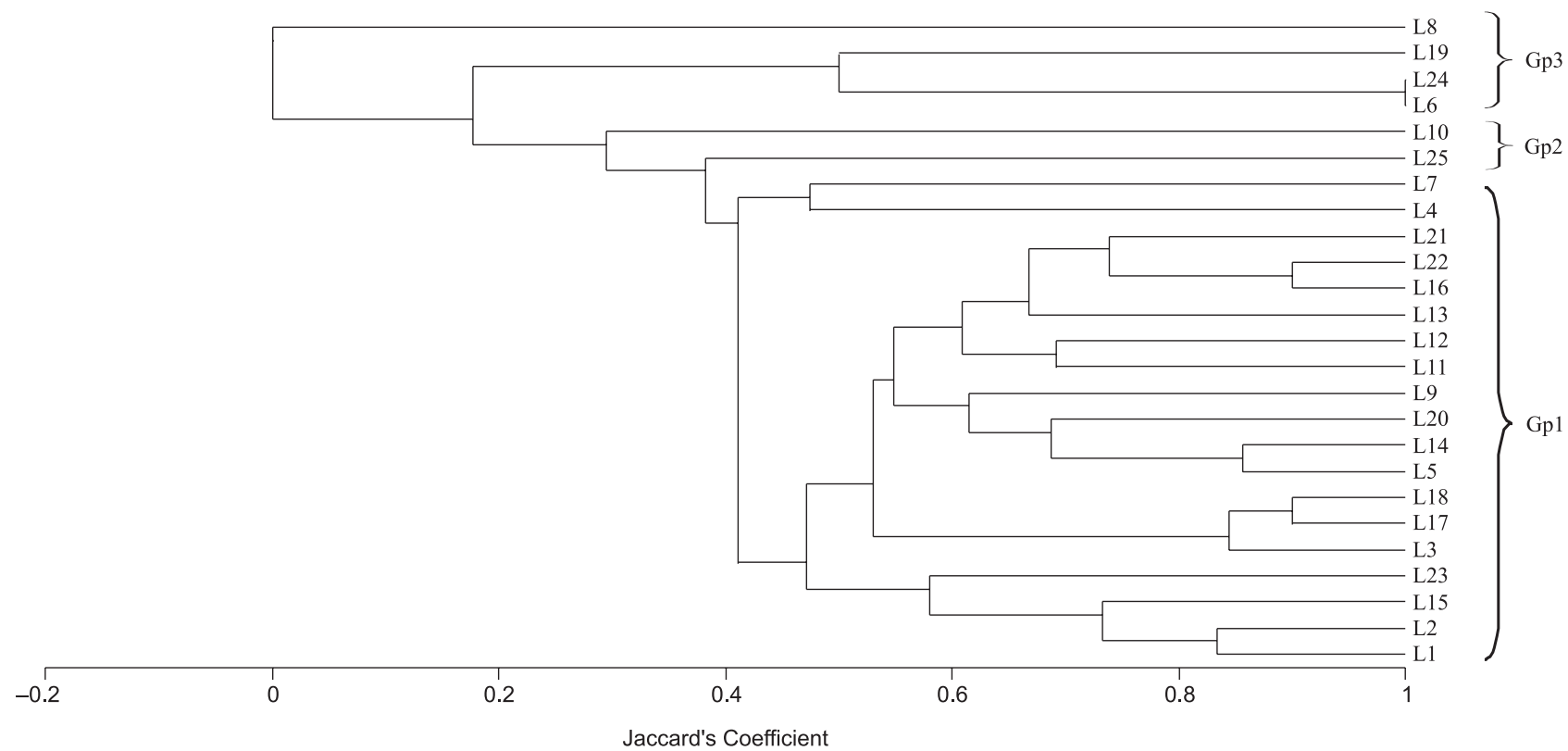

Fig. 4. UPGMA phenogram based on RAPD data using Jaccard coefficient in the total of 25 Tunisian Lawsonia inermis L. germplasm

method showed the differentiation of the L8 individual from Bsissi locality (Fig. 2). The individual L5 from Mdou locality was related of a group comprised three individuals L22, L20 and L17 from different localities. The germplasm L23 from Chatt Essalem was close to the group constituted by the all others germ- plasm. The latter group was divided in to three sub-groups coded as ss-g1, ss-g2 and ss-g3 in Fig. 1.

For the PCO analysis we kept only the germplasm plot defined by the tow first axes 1 and 2 because they showed the high percentage of variation. Therefore, the germplasm plot in the plan defined by the axes 1

Table 6. Jaccard's coefficient matrix for 25 L Lawsonia inermis L. germplasm accessions using RAPD markers

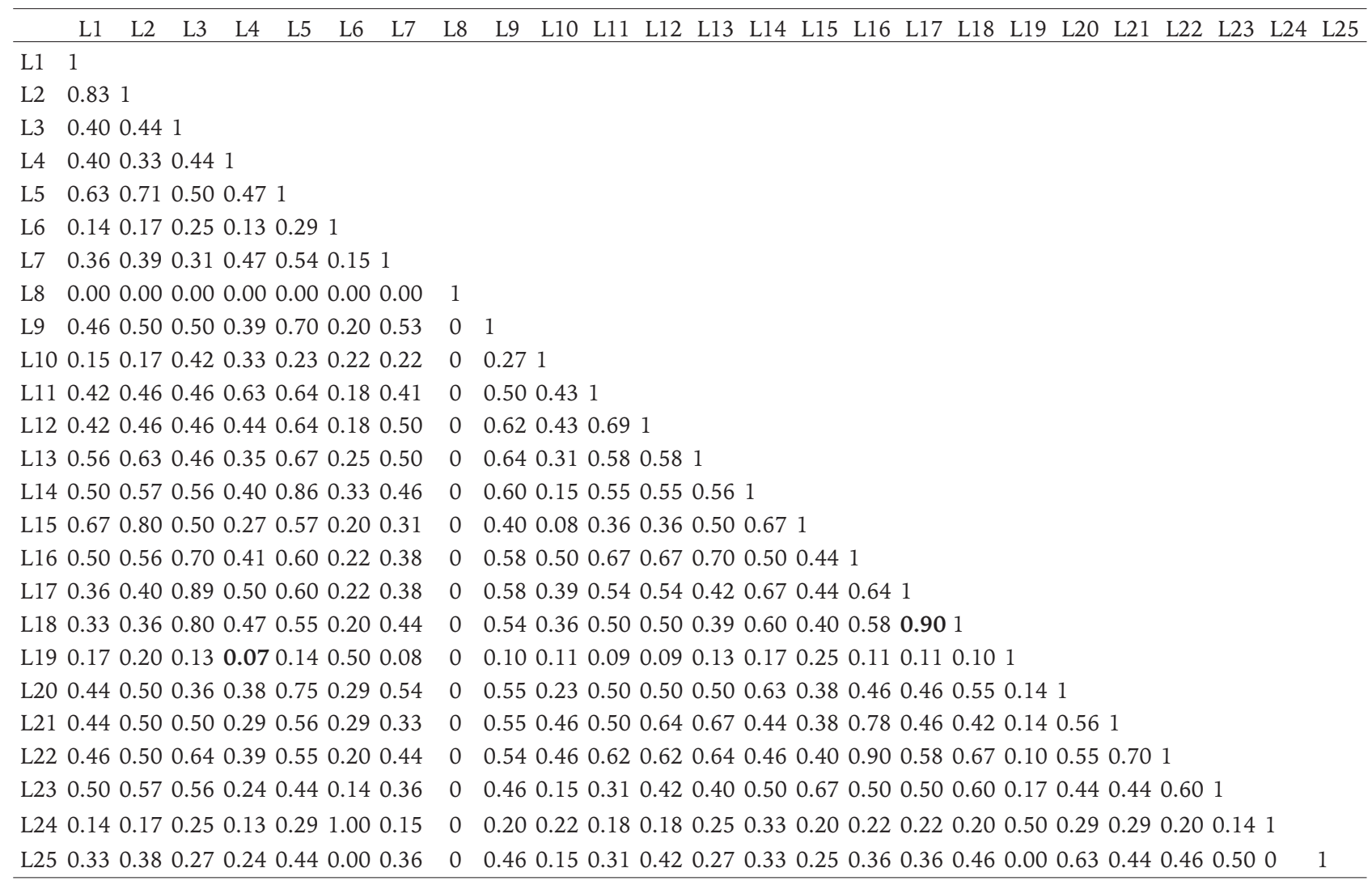


and 2 of PCO analysis (Table 5, Fig. 1) showed the three groups (ss-g1, ss-g2 and ss-g3) constituting the sub-groups in dendrogram. These sub-groups generated by the both PCO and dendrogram analyses did not show any geographical structure. The ss-g1 group gathered germplasm from three localities: L1 from Bou Said, L4 from Mdou, and L7, L9 from Bsissi. The ss-g2 grouped germplasm from Mdou (L2), Bou Said (L2, L3) and Chenini (L10, L11, L12, L13, L16, L18) localities. The last ss-g3 group comprised germplasm from two localities, Chenini (L14, L15) and Chatt Essalem (L21, L23, L24, L25).

\section{RAPD Data}

Genetic similarity indices of the 25 germplasm were calculated (Table 6). The overall MGSI ranged from 0.07 (between L4-MdouI and L20-Chatt EssalemI individuals) to 0.9 (between L17 and L18 from Chenini individuals). Based on the PCO analysis, the plot of germplasm in plan defined by the two first axes (Table 5 and Fig. 3) showed three groups (coded GA, GB and Gp3) independently to their oasis origins. The dendrogram based on UPGMA method divided the studied germplasm in three groups coded Gp1, Gp2 and Gp3 (Fig. 4) differencing to the three groups obtained by PCO analysis (Fig. 3); excepting the group coded Gp3 which is similar from the both PCO and dendrogram. The Gp3 cluster grouped germplasm L6 and L8 from Bsissi, L24 from Chatt Essalem and L19 from Cheneni localities.

\section{Discussion}

In the present work, most of the clusters obtained in the UPGMA phenogram included Lawsonia inermis L. germplasm from various localities. Related genetic relationship was observed between studied germplasm.

The genetic relationship is independently on the geographic origin of Henna germplasm. This result was in agreement with Nowakowska (2009) showing the absence of any connection between genotypes and the spatial distribution of Picea abies in Poland. In other hand, it has been reported that provenances Scots pine separated by the lowest genetic distance are not necessarily situated in the neighboring zones and the genetic structuring among isolated parts of the geographic range of the species may be a result of an ancient fragmentation (Nowakowska 2004). Mazur et al. (2010) reported that the Mantel test showed no statistically significant relationship between Mahalanobis and geographical distances among the studied germplasm of Juniperus phoenicea.

Both the RAPD and ISSR molecular markers have been used in population genetic studies (Parsons et al. 1997; Esselman et al. 1999; Li and Ge 2001). However, no such genetic diversity using molecular mark- ers were reported in the Lawsonia inermis specie. Tunisia as internationally known for Lawsonia inermis of Gabès; the commercial culture of this plant is a specificity of this region. The cultivar "Gabsia", in Tunisia and Libya, characterized by his small leaves such as "Filalia" and "Twatia" in Maroc" (Cardon 2005). It is often said that the small Henna leaves possess the best quality and effectiveness than the large Henna leaves (Cardon 2005). Therefore, the necessity of genetic conservation of Gabès cultivars having small leaves. Collection is highly recommended to preserve the genetic resources that are traditional cultivars, and is often associated with the production site (Cardon 2005).

Maintaining or enhancing the genetic diversity of Lawsonia inermis L. germplasm will promote its ability to adapt to the environment and thus decrease its risk of extinction.

Lawsonia inermis L. germplasm characterize essentially the oases ecosystem in Tunisia and, therefore, were available resources for conservation. Mainly, the perpetual fall from the areas reserved of the Henna culture in the oasis ecosystem. The gradual disappearance of local knowledge mastery of the cultural management of this specie indicated the trend toward extinction of Lawsonia inermis. An increase in human activities may decrease the size of populations and increase the genetic drift. Taking into account these points, efforts should be made to protect all populations and limit human impact. An important aim of any conservation program, however, must be the preservation of genetic variability of Henna from Gabès oases.

On the other hand, the studied Henna germoplasm were characterized by a glabrous leaf with an area varied from $0.381 \pm 0.05 \mathrm{~cm}^{2}$ to $4.17 \pm 0.51 \mathrm{~cm}^{2}$ and by her white flowers varied from $11.1 \pm 3.17$ to $44.6 \pm 11.54$ flower/inflorescence.

\section{References}

Aras S., Duran A., Yenilmez G. 2003. Isolation of DNA for RAPD analysis from dry leaf material of some Hesperis L. specimens. Plant Molecular Biology Reporter 21: 461a-461f.

Boulila A., Bejaoui A., Messaoud C., Boussaid M. 2010. Genetic diversity and population structure of Teucrium polium (Lamiaceae) in Tunisia. Biochemical Genetics 48: 57-70.

Bornet B., Branchard M. 2001. Nonanchored inter-simple sequence repeat (ISSR) markers: Reproducible and specific tools for genome fingerprinting. Plant Molecular Biology Reporter 19: 209-215.

Cardon D. 2005. Ressources végétales de l'Afrique tropicale 3: colorants et tannins. PROTA. 237 p. 
Chaudhary G., Goyal S., Poonia P. 2010. Lawsonia inermis Linnaeus: A Phytopharmacological Review. International Journal of Pharmaceutical Sciences and Drug Research 2: 91-98.

Cartwright-Jones C. 2006. Developing guidelines on henna: a geographical approach. Henna Page Publications: Ohio, USA.

dela Hoz M.P.S., Davila J.A., Loarce Y., Ferrer E. 1996. Simple sequence repeat primers used in polymerase chain reaction amplifications to study genetic diversity in barley. Genome 39: $112-117$.

Endrini S., Rahmat A., Patimah I., Taufiq-Yap Y.H. 2007. Comparing of the cytotoxicity propertis and mechanism of Lawsonia inermis and Strobilanthes crispus extract against sevearl cancer cell lines. Journal of Medical Science 7: 1098-1102.

Esselman E.J., Jianqiamg L., Crawford D. J., Windus J. L., Welfe A. D. 1999. Clonal diversity in the rare Calamagrostis porteri spp. insperata (Poaceae): comparative results for allozymes and random ampli?ed polymorphic DNA and inter-simple sequence repeat markers. Molecular Ecology 8: 443-453.

Hanson L., McMahon K.A., Johnson M.A.T, Bennett M.D. 2001. First nuclear DNA C-values for 25 angiosperm families. Annals of Botany 88: 851-858.

Grieve M., www.botanical.com/botanical/mgmh/h/ henna-24.html in April11, 2005.

Gupta R.P., Singh P., Pandher, M.S. 1992. In: Dev. Microbiol., (eds. Kaushik, B. P.), LARI, New Delhi, pp. 95-101.

Hess R.A., Bunick D., Lubahn D.B., Zhou Q. and Bouma J. 2000. Morphological changes in efferent ductules and epididymis in estrogen receptor-á knockout mice Journal of Andrology 21: 107-121.

Jain V.C., Shah D.P., Sonani N.G., Dhakara S., Patel N.M. 2010. Pharmacognostical and preliminary phytochemical investigation of Lawsonia inermis L. leaf. Romanian Journal of Biology - Plant Biology 55: 127-133.

Jover M.A., del Castillo-Agudo L., Garcia-Carrascosa M., Segura J. 2003. Random amplified polymorphic DNA assessment of diversity in western Mediterranean populations of the seagrass Posidonia oceanica. American Journal of Botany 90: 364-369.

Keheyan Y., Giulianelli L. 2006. Identification of historical ink ingredients using pyrolisis_GC-MC. A model study. e-RESERVATIONScience published by MORANA RTD d.o.o. 3, 5-10.

Kokate C.K. 2001. Practical Pharmacognosy, Vallabh Prakashan, pp. 218.

Li A., Ge S. 2001. Genetic variation and clonal diversity of Psammochloa villosa (Poaceae) detected by ISSR markers. Annals of Botany 87: 585-590.
Makhija I.K., Dhananjaya D.R., Kumar V S, Devkar R., Khamar D., Manglani N., Chandrakar S. 2011. Lawsonia inermis - from traditional use to scientific assessment. African Journal of Pharmaceutical Sciences and Pharmacy 2: 145-165.

Manly B.F.J. 1994. Multivariate statistical methods: a primer. Chapman \& Hall, London.

Mazur M., Klajbor K., Kielich M., Sowińska M., Romo A., Montserrat J.M., Boratyński A. 2010. Intra-specific differentiation of Juniperus phoenicea in the western Mediterranean region revealed in morphological multivariate analysis. Dendrobiology 63: 21-31.

Mikhaeil B.R., Badria F.A., Maatooq G.T., Amer M.M.A. 2004. Antioxidant and immunomodulatory Constituents of Henna Leaves. Zeitschrift fur Naturforschung C - A Journal of Biosciences 59c : 468-476.

Moreno S., Martin J.P., Ortiz J.M. 1998. Inter-simple sequence repeat PCR for characterization of closely related grapevine germplasm. Euphytica 101: 117-125.

Nebauer S.G., Del Castillo Agudo L., Segura J. 1999. RAPD variation within and among natural populations of outcrossing willow-leaved foxglove (Digitalis obscura L.). Theoretical and Applied Genetics 98: 985-994.

Nowakowska J., Jabłonowski S., Mockeliūnaitė R., Bieniek J. 2004. Genetic variability within and among Polish and Lithuanian populations of common ash (Fraxinus excelsior L.) based on RAPD analysis. Baltic Forestry 10(1): 57-64.

Nowakowska J.A. 2009. Mitochondrial and nuclear DNA differentiation of Norway spruce (Picea abies [L.] Karst.) populations in Poland. Dendrobiology 61s: 119-129.

Nowakowska J. 2004. Genetic variation in Scots pine (Pinus sylvestris L.) populations at regional level revealed by random amplified polymorphic DNA analysis. Miðkininkystë 2: 13-20.

Parsons B.J., Newbury H.J., Jackson M.T., Ford-Lloyd B.V. 1997. Contrasting genetic diversity relationships are revealed in rice (Oryza sativa L.) using different marker types. Molecular Breeding 3: 115-125.

Rout G.R., Das G., Samantory S., Das P. 2001. In vitro micropagation of Lawsonia inermis (Lythraceae). Revista de Biología Tropical International Journal of Tropical Biology and Conservation 49: 957-963.

Singh V., Pandey R.P. 1998. Ethnobotany of Rajasthan, India. Scientific Publishers, Jodhpur.

Singh M., Jindal S.K., Singh, D. 2005. Natural Variability, Propagation, Phenology and Reproductive Biology of Henna. Henna, Cultivation, Improvement and Trade: 13 - 18. Jodhpur, India: Central Arid Zone Research Institute. 
Welsh J., Mc Clelland M. 1990. Fingerprinting genomes using PCR with arbitrary primers. Nucleic Acids Research 18: 7213-7218.

Williams J.G.K., Kubelik A.R.K, Livak K.J., Rafaski J.A., Tingey S.V. 1990. DNA polymorphisms amplified by arbitrary primers are useful as genetic markers. Nucleic Acids Research 18: 6531-6535.

Wolfe A.D., Xiang Q.Y., Kephart S.R. 1998. Assessing hybridization in natural populations of Penstemon (Scrophulariaceae) using hypervaria- ble intersimple sequence repeat (ISSR) bands. Molecular Ecology 7: 1107-1125.

Zietkiewicz E., Rafalski A., Labuda D. 1994. Genome fringerprinting by simple sequence repeat (SSR)-anchored polymerase chain reaction amplification. Genomics 20: 176-183.

Zumrutdal M.E., Ozaslan M., Tuzcu M., Kalender M.E., Dag lioglu K., Akova A., Karagoz I.D., Kilic I.H., Colak O., Koksal F. 2008. Effect of Lawsonia inermis treatment on mice with sarcoma. African Journal of Biotechnology 7(16): 2781-2786. 